\title{
РЕЦЕНЗИИ
}

\author{
I. V.Sablin
}

\section{A HISTORY FOR THE CENTENARY OF THE RUSSIAN REVOLUTION}

This review essay focuses on the new monograph by S. A. Smith Russia in Revolution: An Empire in Crisis, 1890 to 1928 (Oxford, Oxford University Press, 2017). As a leading expert in the social history of the Russian Revolution of 1917, Smith provides a comprehensive political, social, and cultural narrative of one of the central events in the global history of the twentieth century. Directed at a general readership, the book offers an excellent overview of existing Russian and Western scholarship, outlines the main course of events, introduces most important actors, and contains thought-provoking conclusions about the revolution. As seen from the title, Smith takes a longish view on the political rupture and includes a comprehensive analysis of social and political life of the Russian Empire, a brief overview of the First Russian Revolution (1905-1907) and the economic and political crisis of the First World War (1914-1918) before discussing the Russian Revolution of 1917, the Russian Civil War, and the period of the New Economic Policy (NEP). The book's conclusion is a comprehensive essay attempting to comprehend the revolution and its consequences as a whole. As a nuanced social, political, and cultural history, Russia in Revolution: An Empire in Crisis, 1890 to 1928 outlines the Revolution of 1917 as a tectonic shift which cannot be reduced to a simple change of the elites in the Russian imperial formation. Smith's brilliant work will be invaluable for the students of history, both in Russia and abroad, and all those who are interested in global history in general and the Russian Revolution in particular. Refs 27.

Keywords: Historiography, February Revolution, October Revolution, socialism, NEP, USSR, Social History.

For citation: Sablin I. V. A history for the centenary of the Russian revolution. Vestnik of Saint Petersburg University. History, 2017, vol. 62, issue 3, pp. 638-644. DOI: 10.21638/11701/spbu02.2017.314

Sablin Ivan - PhD, Senior Researcher Fellow, Center for Historical Research, National Research University Higher School of Economics (St. Petersburg), 16, Soiuza Pechatnikov str., St. Petersburg, 190008, Russian Federation; isablin@hse.ru

Саблин Иван Валерьевич - PhD, старший научный сотрудник, Центр исторических исследований, Национальный исследовательский университет «Высшая школа экономики» (Санкт-Петербург), Российская Федерация, 190008, Санкт-Петербург, ул. Союза Печатников, 16; isablin@hse.ru

The review essay was prepared within the framework of the Basic Research Program at the National Research University Higher School of Economics (HSE), project "Transformation of Regimes of Governing Diversity: Continuity of Imperial Practices and Ruptures of Post-Imperial Political Imaginaries in the History of Russia" (TZ-51) in 2017, and supported within the framework of a subsidy granted to the HSE by the Government of the Russian Federation for the implementation of the Global Competitiveness Program.

(c) Санкт-Петербургский государственный университет, 2017 


\section{И. В. Саблин}

\section{ИСТОРИЯ РУССКОЙ РЕВОЛЮЦИИ В КОНТЕКСТЕ ЕЕ СТОЛЕТИЯ}

Рецензия посвящена новой монографии С. А. Смита «Россия в период революции: кризис империи, 1890-1928 гг.», изданной Издательством Оксфордского университета в 2017 г. Будучи крупнейшим специалистом по социальной истории Русской революции 1917 г., Смит предлагает всесторонний политический, социальный и культурный анализ одного из центральных событий глобальной истории XX в. В книге, рассчитанной на широкого читателя, представлен детальный обзор основной российской и западной научной литературы по теме, освещается основной ход событий, дается краткая характеристика важнейшим их участникам, а также имеются интересные авторские выводы о революции как целостном явлении. Как следует из названия, Смит рассматривает период политического перелома в долгосрочной перспективе и начинает с анализа социальной и политической жизни Российской империи и краткого обзора Первой русской революции 1905-1907 гг. и социального и экономического кризиса Первой мировой войны 1914-1918 гг., переходя затем к анализу Русской революции 1917 г., Гражданской войны и периода новой экономической политики (НЭПа). Заключение монографии - связанное со всем текстом и при этом вполне самостоятельное научное эссе, в котором автор предпринимает попытку охарактеризовать революцию как целостное явление и оценить ее последствия для современного мира. Работа Смита представляет собой детальную социальную, политическую и культурную историю Русской революции 1917 г. как колоссального перелома во всех сферах жизни, а не простой смены политических элит в российской/советской формации. Это превосходное исследование, несомненно, окажется бесценным для всех, кто изучает историю в России и за рубежом, а также тех, кто интересуется глобальной историей в целом и историей Русской революции в частности. Библиогр. 27 назв.

Ключевые слова: историография, Февральская революция, Октябрьская революция, социализм, НЭП, СССР, социальная история.

The centenary of the Russian Revolution of 1917 - or the February and October Revolutions - made the crisis and collapse of the Russian Empire, the Russian Civil War, and the formation of the Union of Soviet Socialist Republics (USSR) key topics in international historical discussions in 2017. Russia in Revolution: An Empire in Crisis, 1890 to 1928 by Stephen A. Smith, issued by Oxford University Press in January 2017 [Smith S.A.2017], occupies a special place among new publications on the subject, for it is a comprehensive work summarizing the last twenty-five years of Russian and Western research which benefited greatly from the opening of archives and internationalization of scholarly discussions. The book, which is intended for general and academic audiences alike, is a major milestone in the international debates on the revolution, its consequences, and its legacies which shaped the global history of the twentieth century. It will undoubtedly make a valuable addition to university, public, and private libraries all over the world.

Smith, who is Senior Research Fellow and Professor of History at the University of Oxford, is undoubtedly one of the leading experts in the history of socialism and revolution in Russia. Having studied inter alia at Moscow State University from 1976 to 1977, Smith was one of the few Western scholars who experienced the Soviet Union in person and worked with archival materials on site before they became widely available to international historians. His first book Red Petrograd: Revolution in the Factories, 19171918 [Smith S. A. 1983] was a groundbreaking social history of the February and October Revolutions of 1917. Focusing on the experiences of factory workers, Smith managed to grasp the revolutionary change in Russia in a more general sense. Smith also made a sig- 
nificant contribution to the history of Communism in China writing A Road is Made: Communism in Shanghai, 1920-1927 [Smith S. A.2000]. His Revolution and the People in Russia and China: A Comparative History [Smith S. A.2008] became a groundbreaking comparative social history of the two countries and revolutions. Smith also published two important books for students and general public - The Russian Revolution: A Very Short Introduction [Smith S. A.2002] and The Russian Revolution [Smith S. A.2011] — and edited The Oxford Handbook of the History of Communism [The Oxford handbook 2014]. Apart from that, he contributed to the studies of the Russian Revolution as member of editorial boards of Revolutionary Russia, Past and Present, Twentieth Century Communism, and other journals.

Russia in Revolution: An Empire in Crisis, 1890 to 1928 treats the Russian Revolution not as a combined term for the February and October changes of government in 1917, but as a longer period of ruptures and transitions between 1890 and 1928. The book is hence about the revolutionary situation and, to a lesser extent, about future revolutionaries in late imperial Russia, about the contradictions of imperial society and economy, about the First Russian Revolution (1905-1907) as a prelude to the 1917 events, about Russia in the global crisis of the First World War, and, ultimately, about the post-imperial political, social, economic, and cultural reconfigurations which made up the Soviet Union of the 1920s. The book is directed at the newcomers to the field, yet Smith also promises to question "some familiar interpretations" in the introduction [Smith S.A.2017, pp. $2-3]$, and he certainly delivers on that. The book is based on secondary literature and published sources, mainly the articles and personal documents of the revolution's participants. Smith critically engages with the conclusions of a broad range of Russian and Western scholars and presents a critical synthetic narrative which indeed sheds new light on the subject. Although Smith devotes a great deal of attention to individuals and their role in the events, he makes a structuralist argument that revolutions "are not created by revolutionaries." The argument is indeed convincing given that Smith ascribed pivotal importance to the First World War which brought not only Russia, but also its other participants to the brink of collapse, with the Ottoman, Austro-Hungarian, and German Empires all dissolving in the process. Smith also makes good use of the "imperial turn" in historiography [Gerasimov et al. 2005; Sunderland 2016] maintaining that "Russia" for him is not an isolated and homogeneous state but rather a composite Eurasian space which, in the early twentieth century, underwent imperial transformation [Smith S. A. 2017, p. 4].

The book consists of seven chapters, with a hundred pages devoted to the background of the 1917 events. Smith provides a comprehensive analysis of the pre-revolutionary Russian Empire up to 1905 and the First Russian Revolution in Chapter 1. He starts the history with the emancipation of the serfs in 1861 and other liberal reforms of Alexander II which promised a peaceful integration of Russia into global capitalist modernity, yet the regicide and the subsequent de-liberalization of the regime under Alexander III and Nicholas II altered development pushing the empire to a crisis stimulated by the disastrous Russo-Japanese War (1904-1905). Smith pays close attention to the Russian Empire as a composite space "ruled on the principle of difference" formulated in social estate, religious, and, to a lesser extent, ethnic categories. It was the shift to seeing difference in national terms which contributed to the imperial crisis. Most importantly, Smith provides a detailed economic and social analysis of the empire highlighting 
agricultural and industrial controversies, as well as rapid urbanization. Yet he does not discard the formation of liberal intelligentsia and its quest for the expansion of civil liberties and political rights in the late nineteenth century. Smith is also sensitive to regional difference when pointing to the fact that in Siberia there was hardly any experience with serfdom and landlordism, which made the agrarian crisis there much less acute than in the black-soil provinces and elsewhere in European Russia [Smith S. A.2017, pp. 4, 9, $13-15,28-42]$.

Chapter 2 focuses on the second attempt to discharge the political and social situation - the controversies and resentment of "autocratic capitalism" - by the combination of suppression of political activity and economic liberalization aimed at the establishment of a small landowner class as a backbone of the Russian autocracy. Although there was still considerable dissatisfaction with the regime - class-based demands were being voiced in view of the circulation of socialist ideas and manifested themselves in a series of strikes peaking in the summer of 1914 - Smith concludes that the government did achieve some success in pacifying the country. Yet the First World War and the immense economic and social mobilization which it prompted exhausted the country, which still had a largely agrarian economy and poor means of communication, triggering the collapse of the regime in February 1917 despite the surge of patriotism. It was in fact the patriotism and the rise of popular dissatisfaction with the government's war effort which provided the future revolution with its political content, while the Workers' Groups under the War Industries Committees laid the foundation for the organized labor and socialist movements [Smith S. A. 2017, pp. 72-77, 81, 91].

Smith follows the conventional path of telling the story of the revolution from "February to October 1917" in Chapter 3. Although the narrative of the main events is concise and thoughtful, one may be left wondering if the Petrograd Soviet really had a democratic mandate unlike the Provisional Government, for it was elected from a handful of workers' and soldiers' groups in Petrograd through an often obscure procedure and had little to do with the majority of the empire's population. Yet Smith's bigger argument that soldiers where the main force in the revolution, for they facilitated the February Revolution, took the "revolutionary politics to the countryside", and ultimately secured the soviet power, is convincing. Although Smith does not refer to the "October seizure of power" as a revolution, one cannot suspect him of downplaying the role of the Bolsheviks in social and economic change. On the contrary, the Bolsheviks are in the foreground of the narrative after Chapter 3, which is indeed justified by their importance. In Chapters 4 to 7 Smith convincingly demonstrates that the October 1917 events were not a revolution in itself, but only the beginning of one - the interpretation that the Bolshevik leadership in fact shared at the time. Smith discusses the Civil War focusing on the Bolsheviks in Chapter 4. Although he does include their contenders and short-term allies into the discussion, the war itself is most important for Smith as the political current of the revolution which began in October 1917 and consolidated Soviet rule by 1920, thanks to the Red Army of some 5.5 million which became the "principal social base of the regime". Smith also briefly discusses the forces other than the Reds and the Whites and reflects on the failure of the "third parties" in civil wars in general [Smith S. A. 2017, pp. 105-106, $115,125,148-159,182,207]$.

Chapters 5 and 6 are devoted to political and social histories of War Communism and the New Economic Policy (NEP). Putting anti-Bolshevik peasant uprisings into the 
broader economic and political context allowed Smith to provide a nuanced history of the revolution in larger social terms. He also convincingly showed that the NEP was initially approved as a temporary measure and therefore did not mean any major retreat in the social and economic currents of the revolution. The abandonment of World Revolution and the emergence of the doctrine of "socialism in one country" in 1924, however, unmasked the limits of the transformation by opening the way for the "rehabilitation of Russia's imperial history and traditions." Smith inscribes the inner-party struggle into the larger debates about the directions of social and economic change, which allows him to distance himself from the ungrounded albeit popular discussions of individual political agency and come up with convincing socio-economic explanations of Iosif Vissarionovich Stalin's ultimate rise to power. Finally, Chapter 7 focuses on the cultural change, art and propaganda, and the life of the society, including family and gender relations, which may be called the revolution in the mind of the people. Smith brilliantly outlines the contradictions between the growing importance of propaganda and the actual "cultural revolution" which resulted in reformed gender relations, increasing literacy, and egalitarianism [Smith S. A. 2017, pp. 234-242, 255-256, 265-276, 285-291, 311-312, 338-345, 350-359, 370-373]. In this respect, Smith's timeframe of the revolution, which does not have a clear beginning and, after the collapse of the empire in 1917, manifests itself in all spheres of the post-imperial life by 1928 , works perfectly and the reader gets a full picture of the events from different perspectives.

The book works as a coherent multifaceted story of the revolution and imperial transformation. Although Smith does touch upon the issue of the global importance of the revolution in the text, one may wonder about the immediate international reception of the events of 1917 to 1928 as well as their consequences for global post-imperial order [Davis, Trani 2002; Schild 1995]. It would also be interesting to see more on the foreign participants of the events [Hara 1989; Moffat 2015] and regional peculiarities of the transformation [Badcock 2010; Badcock et al. 2015; Penter 2000; Raleigh 1986; Smith C. F. 1975]. Even though Smith does include non-Bolshevik actors into the discussion in Chapters 3 to 7 , it would be especially interesting to see more information on liberals, moderate socialists, and conservatives [Rosenberg 1974; Smith S. B. 2011] who found a way to integrate into the new formation. Besides, the reception of the revolution among those of them who formed one of the largest international émigré diasporas would also make a good addition to the story, given that the Russian emigration is still largely disconnected from the history of the revolution, although its members continued to identify with Russia and influence international perception of the USSR [Burbank 1989; Raeff 1990]. In a similar manner, the discussion of nation-building [Smith S. A.2017, pp. 308-310] would have benefited from more non-Russian voices exposing the controversies of the politics regarding nationalities, especially those pertaining to ethnic minorities within the RSFSR and the non-titular nations of the union republics [Hirsch 2005; Martin 2001; Slezkine 1994; Smith J.2013; Suny 1993].

All of the above is certainly an issue of limited print space for such a vast topic. Besides, Smith directs his readers to individual studies of the revolution's different aspects. The formulation of larger inferences about the revolution in the introduction allows Smith to brilliantly grasp the core contradiction of Soviet and post-Soviet history. This includes, for instance, the connection of the Bolsheviks to the idealistic project of the Enlightenment in their quest to facilitate "civilizational progress" in Russia and 
beyond and its ultimate corruption by their "contempt for law and ethics", [Smith S. A. 2017, pp. 6-7]. The conclusion of the book is a comprehensive essay attempting to understand the revolution and its consequences as a whole. It reinforces Smith's structuralist argumentation and highlights the core contradiction in more detail, for the Russian Revolution of 1917 resulted in tyranny, but at the same time did bring about universal citizenship and institutionalization of nationality [Smith S.A.2017, pp. 374-375, 382]. As a nuanced social, political, and cultural history, Russia in Revolution: An Empire in Crisis, 1890 to 1928 sketches the Revolution of 1917 as a tectonic shift which cannot be reduced to a simple change of the elites in the Russian imperial formation. Smith's brilliant work will be invaluable for students of history, both in Russia and abroad, and for all those interested in global history in general and the Russian Revolution in particular.

\section{References}

Badcock S. Politics and the people in revolutionary Russia. A provincial history. Cambridge, Cambridge University Press, 2010, $282 \mathrm{p}$.

Russia's Home Front in War and Revolution, 1914-22. Book 1. Russia's Revolution in Regional Perspective. Ed. by S. Badcock, L. G. Novikova, A. B. Retish. Bloomington, Slavica, 2015, 404 p.

Burbank J. Intelligentsia and revolution. Russian views of Bolshevism, 1917-1922. Oxford, Oxford University Press, 1989, $352 \mathrm{p}$.

Davis D. E., Trani E. P. The first Cold War. The legacy of Woodrow Wilson in U. S. - Soviet relations. Columbia, University of Missouri Press, 2002, 360 p.

Gerasimov I., Glebov S., Kaplunovski A., Mogilner M., Semyonov A. In Search of a New Imperial History. Ab Imperio, 2005, no. 1, pp. 33-56.

Hara T.Shiberia shuppei: kakumei to kanshō 1917-1921 [The Siberian Expedition: Revolution and Intervention 1917-1921]. Tokyo, Chikuma shobō, 1989, 575 p. (In Japanese)

Hirsch F. Empire of Nations. Ethnographic Knowledge and the Making of the Soviet Union. Ithaca, Cornell University Press, 2005, 367 p.

Martin T. The affirmative action empire. Nations and nationalism in the Soviet Union, 1923-1939. Ithaca, Cornell University Press, 2001, 528 p.

Moffat I. C. D. The Allied Intervention in Russia, 1918-1920. The Diplomacy of Chaos. Houndsmills, Palgrave Macmillan, 2015, 317 p.

Penter T. Odessa 1917. Revolution an der Peripherie. Köln, Böhlau Verlag, 2000, 472 p. (In German)

Raeff M. Russia abroad. A cultural history of the Russian emigration, 1919-1939. Oxford, Oxford University Press, 1990, $256 \mathrm{p}$.

Raleigh D. J. Revolution on the Volga. 1917 in Saratov. Ithaca, Cornell University Press, 1986, 376 p.

Rosenberg W.G.Liberals in the Russian Revolution. The Constitutional Democratic Party, 1917-1921. Princeton, Princeton University Press, 1974, 534 p.

Schild G.Between ideology and realpolitik. Woodrow Wilson and the Russian Revolution, 1917-1921. Westport (CT), Greenwood Press, 1995, 173 p.

Slezkine Y.Arctic mirrors. Russia and the small peoples of the North. Ithaca, Cornel University Press, 1994, $456 \mathrm{p}$.

Smith C. F. Vladivostok under Red and White rule. Revolution and counterrevolution in the Russian Far East, 1920-1922. Seattle, University of Washington Press, 1975, 304 p.

Smith J.Red Nations. The Nationalities Experience in and after the USSR. Cambridge, Cambridge University Press, 2013, $408 \mathrm{p}$.

Smith S. A. A road is made. Communism in Shanghai, 1920-1927. Honolulu, University of Hawaii Press, 2000, 315 p.

Smith S. A. Red Petrograd. Revolution in the Factories, 1917-1918. Cambridge, Cambridge University Press, 1983,360 p.

Smith S. A. Revolution and the people in Russia and China. A comparative history. Cambridge, Cambridge University Press, 2008, 249 p. 
Smith S. A. Russia in Revolution: An Empire in Crisis, 1890 to 1928. Oxford, Oxford University Press, 2017, $472 \mathrm{p}$.

Smith S. A. The Russian Revolution. A Very Short Introduction. Oxford, Oxford University Press, 2002, 192 p. Smith S. A. The Russian Revolution. New York, Sterling, 2011, 217 p.

Smith S.B.Captives of revolution. The socialist revolutionaries and the Bolshevik dictatorship, 1918-1923. Pittsburgh, University of Pittsburgh Press, 2011, 432 p.

Sunderland W. The USSR as a Multinational State from the Revolution to the Death of Stalin: Western Scholarship since 1991. Vestnik of Saint-Petersburg University, Series 2, 2016, issue 4, pp. 142-158.

Suny R.G. The revenge of the past. Nationalism, revolution, and the collapse of the Soviet Union. Stanford (CA), Stanford University Press, 1993, 224 p.

The Oxford handbook of the history of communism. Ed. by S. A. Smith. Oxford, Oxford University Press, $2014,688 \mathrm{p}$.

Received: 28.02.2017

Accepted: 10.08.2017 